\title{
On the Mixing of Waters at a Northern Offshore Area of Taiwan
}

\author{
Ching-Sheng Chern \\ AND \\ JOE WANG \\ Institute of Oceanography \\ National Taiwan University, Taipei, Taiwan, R.O.C.
}

(Received 28 April 1990; revised 27 September 1990)

\begin{abstract}
Previous hydrographic surveys show that there exists a permanent upwelling center of Kuroshio subsurface water above the shelf break at the northeast offshore area of Taiwan. The water type of this cold dome is quite different from its Kuroshio origin. This indicates that the upwelling water is being mixed with shelf water and that the mixing is mainly in a vertical direction. The energy source of the mixing is partially supported by the internal tidal motion. A typical example was observed during December 3-4, 1989 from the CTD and ADCP surveys at an anchored station. During the survey period, the Kuroshio intruded onto the shelf and both the hydrographic and current profile data indicated a strong internal tide. The gradient Richardson number is smaller than 1 below $80 \mathrm{~m}$ and is about 4-10 in the thermocline, which is in the $40-80 \mathrm{~m}$ depth range. This indicates that the flow is generally unstable and thus the turbulent mixing is enhanced.
\end{abstract}

\section{INTRODUCTION}

The Kuroshio and the Gulf Stream are both intensified western boundary currents with similar dynamical structures. However, the extent of their interactions with marginal seas is not the same. In the Middle Atlantic Bight, Csnady and Shaw (1983) have shown that the steep continental slope effectively prevents the deep ocean circulation from entering the shelf. In the wide shelf of the East China Sea (ECS), the presence of Kuroshio originated water has long been recognized. A main process for the intrusion of Kuroshio subsurface water is through the upwelling at the shelf edge, and the strongest signal is probably from the persistent upwelling center located on the shelf break northeast of Taiwan (Chern and Wang, 1989). 
In the South Atlantic Bight (SAB), there also exists a similar upwelling associated with the formation of Gulf Stream frontal eddies, but these eddies are transient events, with a residence time of about two weeks, while the upwelled water retains the same $(T, S)$ values when of their Gulf Stream origin (Lee et al., 1981). For the cold dome northeast of Taiwan, its locations always remain at similar places and the upwelled water has quite different $(T, S)$ values as compared with the Kuroshio subsurface water (Chern et al., 1990). This indicates that the upwelled water is being mixed with shelf waters. In this study, we present a typical example of Kuroshio intrusion onto the shelf with strong mixing induced by the internal tidal motions in the winter time.

\section{HYDROGRAPHIC OBSERVATION}

In the past three years, we have made six hydrographic surveys at offshore areas of north Taiwan. Although the data may depend on the weather conditions at each survey time, all results show that there is a cold dome above the shelf break and the presence of Kuroshio subsurface originated water on the lower layer of the shelf (Chern and Wang, 1989, 1990). Fig. 1 shows a typical composite $T-S$ plot of the survey over the shelf and slope region, based on data from the September 1987 cruise. Temperature and salinity data were obtained at each station with NBI CTD sampled at $32 \mathrm{~Hz}$. Original data were smoothed and resampled at $1 \mathrm{~m}$ depth intervals. Each $(T, S)$ point in Fig. 1 corresponds to one sample.

In Fig. 1, the Kuroshio water is marked by high salinity $(>34.5)$ and the shelf water by relatively low salinity $(<34.3)$, and these two waters are well separated in the surface layer. The $T-S$ diagram also shows that the shelf waters are directly mixed with the subsurface Kuroshio water with a $(T, S)$ value at about $\left(16^{\circ} \mathrm{C}, 34.6\right)$, which occurs at the 200-300 $\mathrm{m}$ depth range (estimated from the vertical $T / S$ profiles of the seaward Kuroshio water), and the mixing occurs mainly in a vertical direction. In the surface layer, this mixing may be driven by the wind stress but for waters below the thermocline, the mixing can only be caused by shear instability with the vertical shears supplied from inertial or internal wave motions.

\section{OBSERVATIONS AT THE ANCHORED STATION}

In order to understand the main process that provides the needed velocity shear for the vertical mixing between different waters, we kept the RV Ocean Research I at $25^{\circ} 30^{\prime} \mathrm{N}, 122^{\circ} 1^{\prime} \mathrm{E}$ during December 3-4, 1989 to monitor the hydrographic and current profiles. The CTD casts were done once per hour and the ship mounted ADCP measurement was made continuously with a sampling 


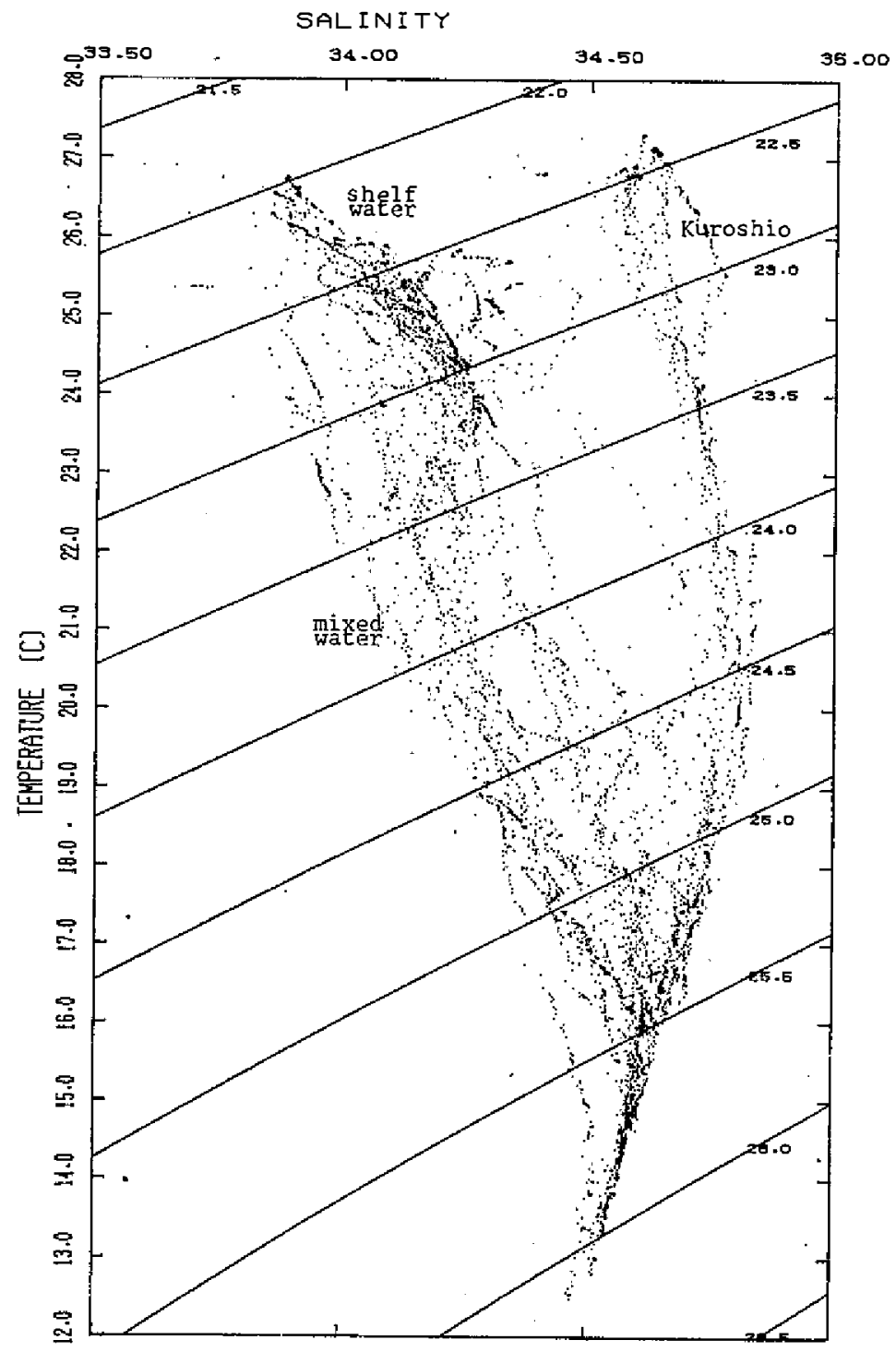

Fig. 1. Composite $T-S$ plot of all hydrographic station data taken during 14 to 19 September 1987.

interval of 5 minutes.

Fig. 2 shows the stick diagram of currents at the $20 \mathrm{~m}, 50 \mathrm{~m}$ and $80 \mathrm{~m}$ depth level and the surface temperature during the survey period. The currents are mainly northwestward with a temperature of about $24^{\circ} \mathrm{C}$. Since the daily averaged velocity is northwest at all depths and the salinity is about 34.3-34.6, Fig. $3 \mathrm{~b}$, this indicates the intrusion of Kuroshio originated water onto the the shelf at this site. The current variations are dominated by the semi-diurnal tidal constituent and even from the relatively weak variation of surface temperature, 
we can still infer this tidal effect. There is a tendency for surface temperature increases of over $24^{\circ} \mathrm{C}$ as the water turns toward northeast and decreases as the water flows westward, but the increase of water temperature after 10 a.m. on December 4 may be due to other effects.
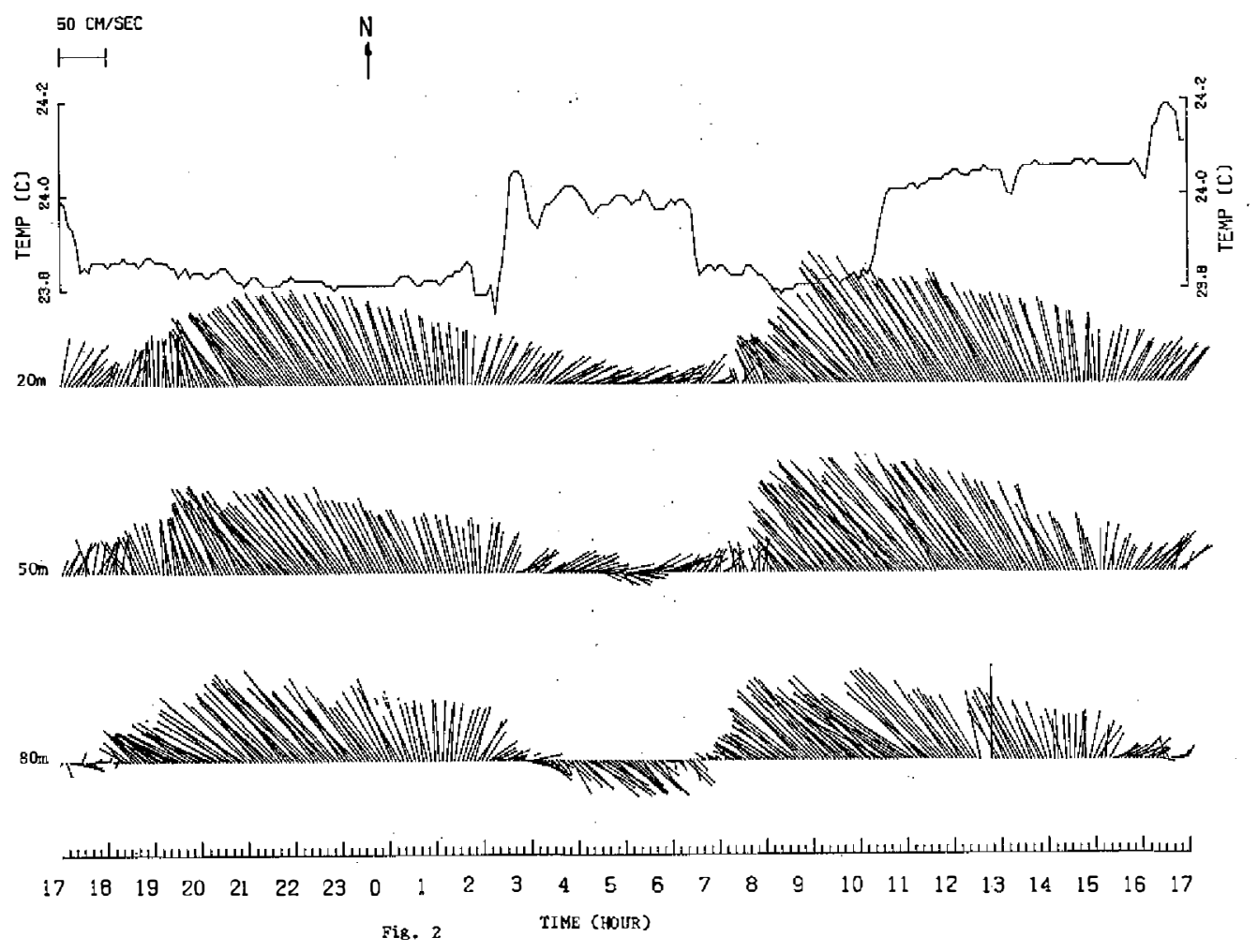

Fig. 2. Stick diagram of currents at $20 \mathrm{~m}, 50 \mathrm{~m}$ and $80 \mathrm{~m}$ and the surface temperature measured from ship mounted ADCP at an anchored station during Dec. 317 p.m. to Dec. 417 p.m. 1989.

Figs. 3a, 3b shows the depth variations for constant temperature and salinity levels. The existence of an internal tide of semi-diurnal constituent is obvious and its amplitude is about $40 \mathrm{~m}$. The temperature variation also shows that except for the period between 10 a.m.-15 p.m., the rising of low temperature water beneath the thermocline is accompanied by an increase of surface temperature of over $24{ }^{\circ} \mathrm{C}$. This $180^{\circ}$ out of phase between the temperature below the thermocline and at the surface indicates the internal tide is at the lowest mode at the interface.

From the lowest internal wave mode theory, we know that the vertical gradient of the horizontal velocity is large on the thermocline itself and the shear magnitude is proportional to the strength of stratification (Phillips, 1977). The 
(a)

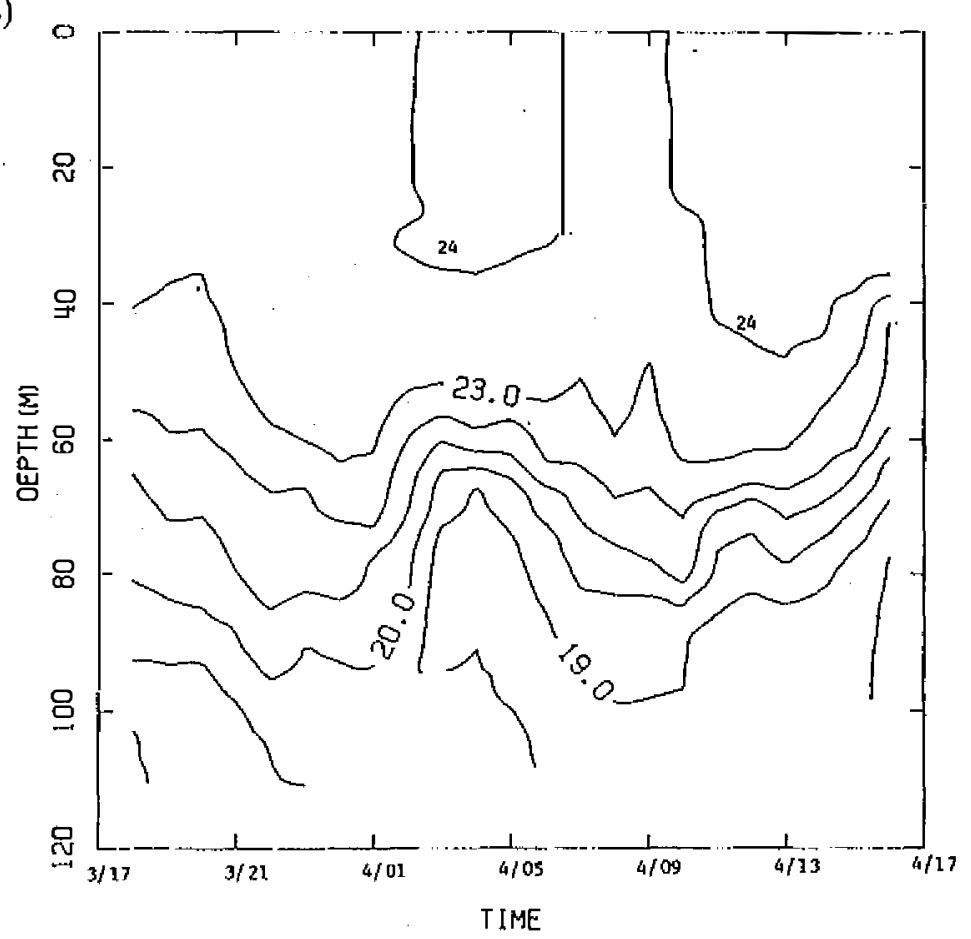

(b)

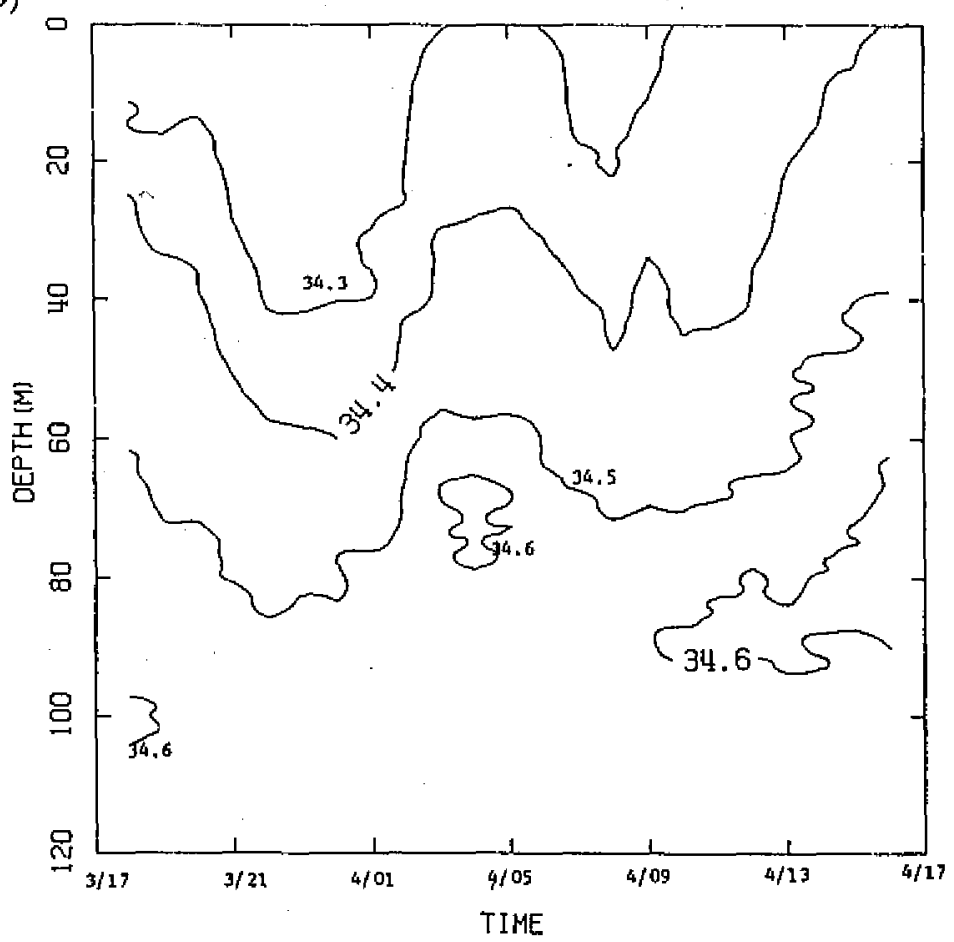

Fig. 3. (a) Depth variations of constant temperature (in ${ }^{\circ} C$ ) and (b) salinity measured from CTD at the anchored station during the survey time as in $F i g .2$. 
data from the ADCP measurement should reveal this result. Fig. 4 shows the time variation of the velocity shear magnitude, which is computed from the hourly averaged velocity profiles. The data of the first two bin cells, which are $8 \mathrm{~m}$ deep, were discarded to avoid the influence of surface waves. In general, the velocity shear in the mixed layer is weak and increases above $1 \mathrm{~cm} \mathrm{~s}^{-1} \mathrm{~m}^{-1}$ beyond the $40 \mathrm{~m}$ depth. The time variation of the depth, where the shear strength is $1 \mathrm{~cm} \mathrm{~s}^{-1} \mathrm{~m}^{-1}$, agrees well with the thermocline variation in the temperature profiles (Fig. 3). At depths beyond $80 \mathrm{~m}$, there still exists quite a large velocity shear with a magnitude of about $1-2 \mathrm{~cm} \mathrm{~s}^{-1} \mathrm{~m}^{-1}$.

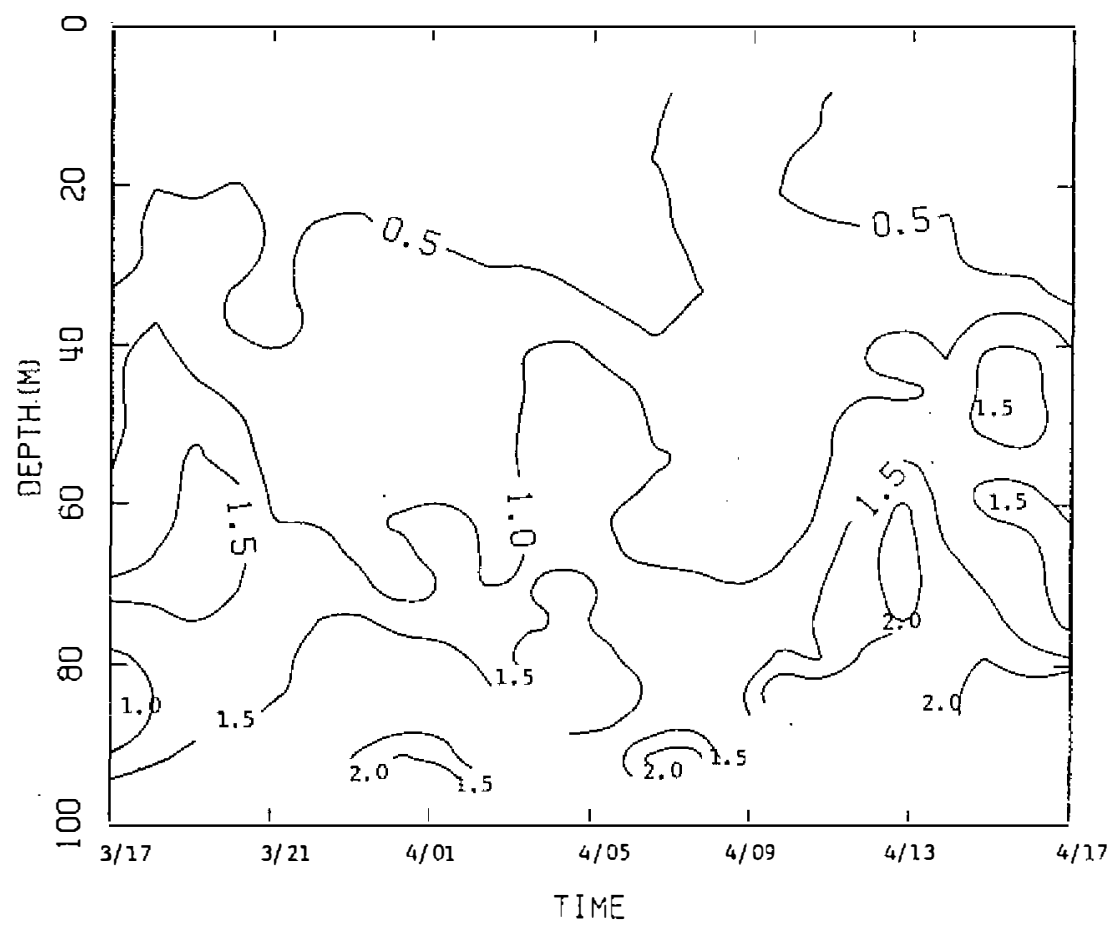

Fig. 4. Depth variations of current shear strength (in $\mathrm{cm} \mathrm{s} \mathrm{s}^{-1} \mathrm{~m}^{-1}$ ) calulated from the hourly averaged ADCP velocity profiles during the survey time as in Fig. 2.

By using the current meter measurements, moored at 15, 60 and $110 \mathrm{~m}$ depth from a nearby station, Chern (1986) showed that the difference of currents measured at the $60 \mathrm{~m}$ and the $110 \mathrm{~m}$ depth level agrees well with the prediction from a simple Ekman type bottom boundary layer model, and that the measured current shear remains highly coherent with the tidal variation at Keelung harbor. However, for the difference of currents at the $15 \mathrm{~m}$ and the $60 \mathrm{~m}$ depth, its magnitude is much larger than the model prediction and has lower coherence with the tide at Keelung. Therefore, we may infer that the current shear near the thermocline, at the $40-80 \mathrm{~m}$ depth range, is caused by 
the internal tide and the shear at a lower level is caused by the bottom friction.

We also computed the vertical gradient Richardson number, $\mathrm{Ri}$, from each CTD cast and the hourly averaged ADCP data for the same time. Fig. 5 shows the $\mathrm{Ri}$ profile which in general is smaller than one below $80 \mathrm{~m}$ and is about 4-10 on the thermocline. Generally, the Richardson number is above 100 in case of very stable stratification. Hence the relatively small $R i$ values indicate that the flow is unstable and turbulent mixing is enhanced.

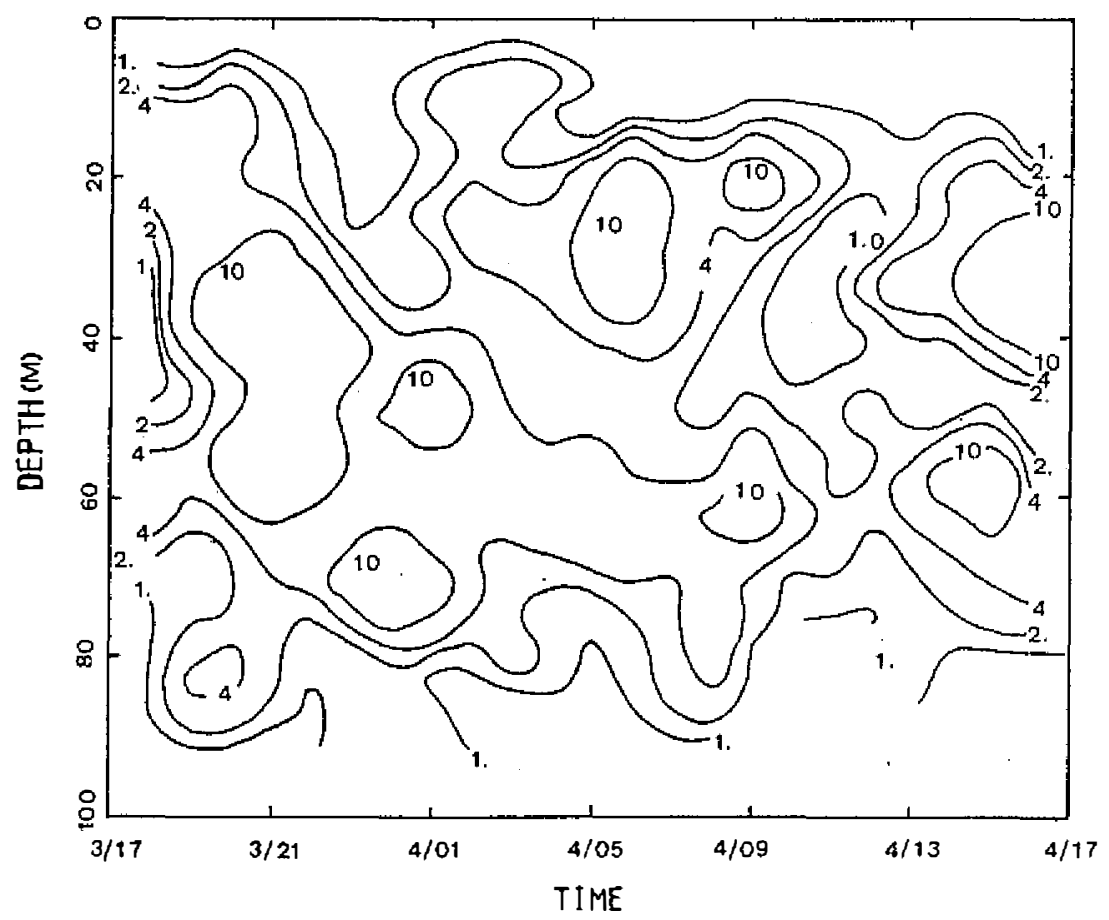

Fig. 5. Depth variations of constant gradient Richardson number calculated from the CTD data and the hourly averaged ADCP velocity profiles during the survey time as in Fig. 2.

In summary, the CTD and ADCP surveys at this anchored station indicate that the Kuroshio intrudes onto the ECS during the survey period and that there exists internal tidal motion, which is of the lowest mode interfacial wave on the thermocline. The vertical mixing of the upwelling Kuroshio subsurface water and the shelf water occurs through the velocity shear of the internal tides.

\section{DISCUSSION}

As Kuroshio passes the north tip of Taiwan, it encounters the sharply curved steep continental slope of the ECS. An upwelling center of the Kuroshio subsurface water is formed above the shelf break at that place. The $(T, S)$ points 
of the CTD survey on the shelf and slope region north of Taiwan are roughly located in straight lines between the shelf water and the subsurface Kuroshio water. This indicates the direct vertical mixing between these waters.

At the northern offshore area of Taiwan, the water depth is about $120 \mathrm{~m}$. The.present survey shows that there exists an internal tide with an amplitude as large as $40 m$ on the thermocline with the sigma-t varied about 1-2 across it. The velocity shear of the internal tide is the energy source of the vertical mixing in this region. In such an active mixing region, there must be a continuous inflow of cold water in order to maintain the observed strong stratification and the internal wave motions. The persistent upwelling of Kuroshio subsurface water above the shelf break provides this cold water source.

It is interesting to note that the shelf-edge upwelling also occurs in the SAB (Bane et al., 1981). In contrast to the persistent and active mixed upwelling center northeast of Taiwan, the upwelling in the SAB is generally associated with transient spin-off eddies and will travel with the stream. Those upwelled waters retain their original properties.

Acknowledgements. This research was supported by the National Science Council under the contract Nos. NSC78-0209-M002a-14 and NSC79 -0209M002a-07. Critical comments by the reviewers are appreciated.

\section{REFERENCES}

Bane, J. M. Jr., D. A. Brooks and K. R. Lorenson, 1981: Synoptic observations of the three-dimensional structure and propagation of Gulf stream meanders along the Carolina continental margin. J. Geophys. Res., 86, C7, 6411-6425.

Chern, C. S., 1986: On the vertical structure of tidal currents at the northern offshore of Taiwan (II), Acta Oceano. Taiwanica, 16, 27-35.

Chern, C. S. and J. Wang, 1989: On the water masses at northern offshore area of Taiwan, Acta Oceano. Taiwanica, 22, 14-32.

Chern, C. S. and J. Wang, 1990: Technical report of research supported by National Science Council under the contract No. NSC78-0209-M002a-14.

Chern, C. S., J. Wang and D. P. Wang, 1990: The Exchange of Kuroshio and East China Sea Shelf Water, Accepted for publication in J. Geophys. Res..

Csnady, G. T. and P. T. Shaw, 1983: The "insulating" effect of a steep continental slope. J. Geophys. Res., 88, 7519-7524.

Lee, T. N., L. P. Atkinson and R. Legeckins, 1981: Observations of a Gulf stream frontal eddy on the Georgia continental shelf, April 1977. Deep Sea Res., 28A, No.4, 347-378.

Phillips, O. M., 1977: Dynamics of the upper ocean, 2nd edition, Cambridge 
University Press, 336pp. 


\title{
台灣北部海域水團混合的現象
}

\author{
陳愿生王曹 \\ 台灣大學海洋研究所
}

摘要

在台瀿東北外海, 由於地形的阻擋, 黑潮次表層水涌出水面, 在陸棚邉緣生成一個冷渦 ○冷渦的水文特性與黑潮水明顯不同。逼個現象表示冷水湧升的過程中與陸棚水產生了混合 ，而且混合主要發生在垂直方向。維持混合所需的動態部份是由內潮波運動所提供。本文根 據船上CTD及ADCP在定點觀椡的結果描迅了一個典型的例子。在觀測期間黑潮流入東海, 而 且水文與海流資料都顯示很强的內潮波存在。在水深 80 米以下, 李氏數 $\mathrm{Ri}$ 小於 1 , 而在斜溫

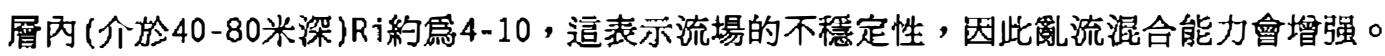

